\title{
The Image of Ali Ibn Abi Talib in Al-Sihah Al-Sittah
}

Maryam Hashemi

Master of Theology and Islamic Studies (Quran Sciences and Hadith), Graduated from Islamic Azad University, Tehran North Branch, Tehran, Iran Mohammad Reza Besharati

Graduated from Sharif University of Technology, Tehran, Iran

\begin{abstract}
Today, we live in a world in which materialistic schools work to prevail over cultural affairs and protest upon spirituality. In such an atmosphere, introducing Imam Ali (A.S.) as a model of asceticism, science, justice, anti-oppression, bravery, and Islamic kindness can bring hope and liberation for today's human beings. For this, it is essential to demonstrate the kind of attitudes and views of Islamic religions towards Imam Ali (A.S.) and introduce his virtues and characters from their words. Depicting the image of Imam Ali (A.S.) in Kutub al-Sittah of the Sunni hadith, which is a well-known Sunni hadith collection, enables us to reach our objectives. The authors of Kutub al-Sittah have confirmed the great moral and scientific characteristics and endeavors of Imam Ali (A.S.) and the interest of the Prophet Muhammad (PBUH) to him by narrating a part of virtues and characters of Molaye Mottaghian.

About Imamah and Wilaya (Guardianship of the Islamic Jurist), there are few but succeeding narrations in Kutub al-Sittah, which can be a valuable way to prove his proficiency for the Wilaya and leadership of the ummah after Muhammad (PBUH). Though the authors of Kutub al-Sitta have worked to justify the process of the Caliphate after the death of Muhammad (PBUH) by narrations to deny his administratorship, especially from Aisha Bint Abi Baker, it is plausible to realize his preponderance in leading the religious and materialistic affairs of the people, after the Prophet (PBUH) by reviewing Kutub al-Sittah of the Sunni hadith and according to the narrations on virtues and characters of Imam Ali (A.S.).
\end{abstract}

Keywords: Ali Ibn Abi Talib, Kutub al-Sittah of the Sunni hadith, Al-Sihah Al-Sittah,

\section{Preface}

History knows him. He is a wonder of creation, the indomitable spirit, and the trouble-shooter hand that assists Muhammad (PBUH) in all stages of his invitation.

Amir Al Momenin Ali (A.S.) is not simply an Imam for Shiites. He is human capital and a divine gift to all human beings who are endeavoring truth, justice, and spirituality, and failure to know him and resort to him is an eminent loss to all humans. During his ups and downs, and life that was full of conflict and effort, Imam Ali (A.S.) faced severe storms that arose from ignorance and aristocracy and ethnic and tribal privileges. However, he sailed the ship as a patient and insightful captain. 
After the passing of Muhammad (PBUH) and the events that deviated the leadership of the ummah from its natural path, the disagreement among Muslims over the caliphate began waves of sedition targeting the unity of Muslims.

Throughout the history of Islam, some have endeavored to take advantage of these differences for their own evil desires. Therefore, we are liable to counterpoise their wicked conspiracies by following the Islamic religions.

An important and practical way to restore and strengthen the unity of Muslims is to study the debated matters discreetly and rationally. Studies away from sectarian biases and persistent efforts to illuminate the dark corners of historical and scientific arguments can pave the way for solid unity.

\section{Purpose and importance of the subject}

Kutub al-Sittah holds a special influence and standing among the Sunni brothers. Therefore, knowing the image of Imam Ali (A.S.) in this collection can assist us to know their views and opinions on issues such as the leadership and Imamah of Amir Al Momenin and his virtues and characters. We hope these studies be efficient in helping our great and valuable goal, which is approaching Islamic religions. Therefore, the importance and purpose of this study are revealed and we assume that the result of these studies can help more Muslims of the world to benefit from this solid thread and strong divine rope. Failure to know a character like Imam Ali (A.S.) is a great loss not only for Muslims but also for humanity.

\section{Research questions}

We attempt in this study to offer appropriate and worthy responses to the questions below:

1. What is the opinion of the authors of Kutub al-Sittah towards the character of Imam Ali (A.S.)?

2. What are the main features and attributes of Imam Ali (A.S.) from the perspective of Kutub alSittah?

3. What is the viewpoint of the authors of Kutub al-Sittah on the issue of Imamah and the Caliphate of Amir Al Momenin (A.S.)?

4. What are the results of studying the image of Amir Al Momenin in Kutub al-Sittah?

\section{Research Hypotheses}

1. Authors of Kutub al-Sittah seem to show lots of respect for Imam Ali (A.S.) as an honorable companion and the fourth caliph of the Muslims.

2. Given the personal tendencies of the authors of Kutub al-Sittah and the political and social conditions at the time of writing, we fail to find many hadiths regarding the Imamah and guardianship of Imam Ali (A.S.) in Kutub al-Sittah. 
3. There are narrations on the virtues and characters of Imama Ali (A.S.) in Kutub al-Sittah. However, these narrations do not cover all his virtues and moral excellences.

4. In general, the attitude of the author of Kutub al-Sittah towards Amir Al Momenin is completely positive, indicating respect and humility towards him.

\section{Research Methodology}

This study was based on a descriptive-analytical approach, composing of two parts, including the study and classification of hadiths narrated for Imam Ali (A.S.) in Kutub al-Sittah, and an overview of the hadiths narrated by him in Kutub al-Sittah.

The study attempts to cover issues and narrations that have been discussed in hadith or narration of at least one of the Kutub al-Sittah. For this, prominent and successive hadiths that have been narrated in other authentic Sunni hadith (not in Kutub al-Sittah) were excluded.

\section{Literature Review}

Prominent historical and hadith books of Sunnis and Shiites allocate many pages to record the events of life, lectures, descriptions of the battles and sacrifices of Imam Ali (A.S.) for Islam and his asceticism, knowledge, and unwavering support of Muhammad (PBUH). However, we have only limited resources because this study aims to present the image of Imam Ali (A.S.) in Kutub al-Sittah. A relevant book is Fazael Al-Khamsah Men Al Kutub al-Sittah wal Qeyroha Men Al Kutub al-Motabareh) (quintic excellences from Kutub al-Sittah and others from prominent books) by Seyyed Morteza Firouzabadi (1410 AH). Mosou'a (war knowledge) of Imam Ali (A.S.) in Ketab Wal Sonnat (the book and tradition) by Reyshahri has also covered the hadiths of Kutub al-Sittah about the personality and life of Imam Ali (A.S.).

Allameh Askari in some parts of the book "Ma'alim al-madrasatayn", and in his other book "Imamah of Imam Ali (A.S.) in Ketab and Sonnat" (Imamah of Imam Ali (A.S.) in book and tradition) provided useful information on this subject. Moreover, Allameh Amini's valuable book "Al-Ghadir" is one of the best books written on this subject. Seyyed Hashem Bohrani in the book "Ali (A.S.) and the Sunnah", which has been translated into Persian and published under the title of Imam Ali (A.S.) in the book and Sunnah, has collected the hadiths of reliable and well-known Sunni sources about Imam Ali (A.S.). There are two other books written on the image of Imam Ali (A.S.) from the point of view of Sunnis. These books have covered hadiths and narrations from reliable Sunni sources, including Kutub al-Sittah. These books include "The position of Imam Ali (A.S.) Near the Caliphs and their Descendants and the Honorable Companion" by Najmuddin Sharif Askari and the book "Imam Ali (A.S.) in the Opinions of the Caliphs" by Mahdi Faqih Imani. 
All the above books have discussed the image of Imam Ali (A.S.) from the point of view of the Sunnis. Furthermore, the hadiths quoted in Kutub al-Sittah have also been mentioned.

\section{Research Organization}

This manuscript was organized into three chapters. The first chapter provides an overview of the structure of the research. The second chapter deals with the elements of research, which includes a brief look at the history of Sunni hadith from the Prophet Muhammad (PBUH) to the advent of Kutub al-Sittah in the third century AH. A part of the second chapter is intended to introduce Imam Ali (A.S.) from the perspective of books "Tarajem" and "Rejal". The third chapter covers the main topic, which contains the hadiths of Kutub al-Sittah about the personality and life of Amir Al Momenin (A.S.), including 1) Imamah of Imam Ali (A.S.) and 2) virtues and characters of Imam Ali (A.S.).

Then, hadiths narrated by Imam Ali (A.S.) in Kutub al-Sittah are briefly reviewed.

In conclusion, we will conclude and respond to the questions asked at the beginning of the manuscript about the image of Imam Ali (A.S.) in Kutub al-Sittah.

\section{A glance at the history of Sunni hadith}

The authors of Kutub al-Sittah have collected and compiled these hadith collections in the third century AH from hundreds of thousands of hadiths narrated from the Prophet Muhammad (PBUH) and his companions.

The question in the mind of the reader is that why authors did write these books in the third century. And whether or not a delay in compiling and organizing the hadiths of the Prophet Muhammad (PBUH) has hurt the text and document of these hadiths.

Therefore, it is essential to quickly refer to the process of collecting and writing the hadith from the first to the third century $\mathrm{AH}$.

\section{Quotation and writing hadiths during the time of the Prophet Muhammad (PBUH)}

During his lifetime, the Prophet Muhammad (PBUH) was teaching and demonstrating the principles of Islam to the public. These teachings were sometimes in the form of talks and discourses, and sometimes in the form of responses to the questions asked by people.

People further were narrating the words they heard from others orally or in writing.

These narrations were sporadical during his lifetime. However, during his talks, the Prophet Muhammad (PBUH) sometimes cautioned people against misrepresenting his words and affirmed the position of those who lied to him in the hellfire.

However, in many narrations, we can see that the Prophet Muhammad (PBUH) encouraged people to narrate his words and convey them to others. 
In Sahih Muslim, a narration from the Prophet Muhammad (PBUH) says "It's no problem to narrate from me". [Sahih Muslim; Ketab Al Zohd; 72/2298/4].

Another reason for the Prophet Muhammad (PBUH) to not preventing others from writing and narrating his narrations is collecting and compiling some scriptures during his life. Sahifa Sadeghe, Sahifa Hommam, and Sahifa Ali are among these books.

Abd Allah ibn 'Amr ibn al-'As (65 AH) wrote the Sahifa Sadegheh from the narrations of the Prophet Muhammad (PBUH) during his life and this action was not opposed by the Prophet Muhammad (PBUH). Ali ibn al-Athir has narrated the number of narrations in Sahifa Sadeghe as one thousand. [Ali ibn alAthir; Asad Al Ghabeh; 245/3].

Sahifa Hommam is a book that was compiled in the first half of the first century (AH). [Hommam Ibn Monabah was the student of Abu Harireh] [Learnings, General History of Hadith; p 65 and 66].

In addition, numerous narrations have been narrated about Sahifa Ali (A.S.) in Sahih Bukhari, Sahih Muslim, Al-Sunan al-Sughra, and other prominent Sunni hadith sources, which have been written texts related to specific topics.

In his Sahih, Bukhari has narrated hadiths about the Sahifa nine times with slight alterations in the text. For example, in "Kitab al-Elam", he has narrated as follows:

"This Sahifa contains contents and narrations about Eghl [an atonement for murder], the freedom of prisoners, and that Muslims are not killed because of an infidel. [Sahiha Bukhari, 118/1]

Bukhari has cited the book Sahifa Bukhari in books Elm (Science), Jihad, Bab Al Diyat, Bab Al Medina, Hajj, Bab Al Zameh Al Muslims, and more.

In a narration, Muslim has narrated that "boundaries of Medina and the two mountains Mount Thawr and Mount Ghayr are among the contents of this Sahih. [Sahia Al Muslim; 467/995/4].

Among the hadith writings of the time of the Prophet Muhammad (PBUH) we can mention the Sahifa of Sa'd ibn 'Abadah Ansari, Samra ibn Jundab, Ibn Abbas, and Jabir ibn Abdullah Ansari. [Readings, General History of Shiite; p 62-65].

The book Rajali Al Shiite has introduced some of the companions of the Imams who were writing hadiths in the first century, including the book Abu Rafi "Al-Sunan Wal-Ahkam Wal-Qadhaya", the book of Asbagh Ibn Nubata Majashi, Zayd Ibn Wahb Jahani, Abu Dharr al-Ghifari, the edition of Salman Farsi containing the hadith of Roman Jathliq, and more. [Readings, A Search to the History of Shitte Hadith; $p$ 68-75]

These were examples that indicated that the quoting of hadiths was not forbidden in the time of the Prophet Muhammad (PBUH). 


\section{Quoting and writing hadith during the time of triplet caliphs}

During the time of the triplet caliphs, people were banned from quoting and writing hadith. Zahabi has quoted in Tazkerat al-Hifaz that "Abu Bakr gathered the people after the Prophet Muhammad (PBUH) and said that if you quote a hadith from the Prophet Muhammad (PBUH) in which you disagree, then those who come after you will face more disagreements. Thus, avoid quoting a hadith from the Prophet Muhammad (PBUH). If someone asks you, then, say that the Qur'an is among us, and consider halals (lawful) as halal and harams (sacred) as haram. [Tazkerat al-Hifaz; 3/1]

Zahabi has written about quoting the hadith of the Prophet Muhammad (PBUH) during his lifetime:

"Omar imprisoned three of his companions, i.e., Ibn Mas'ud, Abu Darda 'and Abu Mas'ud Al-Ansar, in Medina, and said that you had narrated a hadith from the Prophet Muhammad (PBUH) too much.

Hosseyni Jalali writes:

"Omar was very strict in preventing the narration and writing of hadith, and this severity was begun with saying the phrase "Ahsabna Kitabullah" [The book of God is sufficient for us] on the bed of the Prophet Muhammad (PBUH) and proceeded on to burn the books of hadith during his caliphate." [Tadvin Al Senat Al Sharifa; p 275]

The policy of preventing the compilation and narration of hadith was further pursued during the time of Uthman. [Abu Riah; Azva' Al Sonnahh Al Medina, p 54]

In general, Sunni scholars have provided three reasons for the motivation of the triplet caliphs to prevent the transmission and writing of hadith:

1. Preventing disputes and separation among Muslims

2. Preventing the opposite attitude towards the Prophet Muhammad (PBUH)

3. Preventing the assumption that the Qur'an is insufficient to lead human beings

However, Shiite scholars state that this prevention is rooted in the socio-political events of the beginning of Islam and actions to avoid the transmission and writing of hadiths on the virtues and characters of Imam Ali (A.S.), especially the narrations on his guardianship and succession. [Hosseyni Jalali; Tadvin Al Senat Al Sharifah, p 413]

\section{Narration and writing of hadith in the time of the Umayyads}

During the time of the Umayyads, the policy of the first three caliphs was pursued. Moreover, the policy of supporting and disseminating the Mawdu' hadith and the filthy and sinister policy of insulting Imam Ali (A.S.) on the pulpits was adopted.

Scholars of Mu'awiyah's court, such as Ka'b al-Ahbar, counterfeit narrations on the virtues of the triplet caliphs and condemn of Imam Ali (A.S.), and the government supports them. People such as Ka'b alAhbar and Tamim Dari receive permission to narrate hadiths from the time of Umar and are supported. 
[Ibn Hajr, Al Esabe Fi Tamiz Al Sahaba; 473/4; Askari, Al Qur'an Al Karim Wal Revayat Al Modaresetayn, 428/2].

Other Umayyad rulers have also pursued this policy until the time of Umar ibn Abdul Aziz, who came to the caliphate in $99 \mathrm{AH}$. He, who ruled the judiciary, made reforms. For example, he opposed insulting Imam Ali (A.S.) during talks and issued an official order to write and compile the hadith. Further, he returned Fadak to Ahlul Bayt.

After the official order of writing hadith by Umar ibn Abdul Aziz and in general from the second century onwards, hadith compositions, documents, books, and traditions appeared.

\section{Consequences of preventing hadith quoting and writing}

The prohibition of quoting and writing the hadith of the Prophet Muhammad (PBUH) had some adverse consequences, including forgetting some of the hadiths of the Prophet (PBUH), the predominance of quoting to meaning in the narrations, and the emergence of causal hadiths, Isra'iliyyat, and storytelling in the field of hadith.

\section{Narration and writing of hadith in the time of Bani 'Abbas}

From the second century AH, when intellectual and cultural currents developed, the Abbasid rulers supported the compilation of hadiths for various reasons, including standing against the Imams.

At first, the hadiths were not common and had no subject and title, and the narrators of the hadiths were collecting them. Then, the collections and books of hadith were gradually extended conceptually. The book Muwatta Imam Malik was the first book to be compiled. Then Masanid (documents) and Kutub alSittah appeared.

\section{Kutub al-Sittah in Sunni hadith}

In the third century AH, Kutub al-Sittah of Sunni hadith was compiled and written, which included books of Sahih Bukhari and Sahih Muslim (known as "Sahihin"), and the four books of Sunan Abu Dawood, Sunan al-Tirmidhi, Sunan al-Nisa'i, and Sunan Ibn Majah (known as the Sunnah of Arba'a).

Some Sunni scholars have overstated the authentic narrations and are very biased in this regard, and consider all the narrations of these two books to be correct and valid.

Muhammad ibn Yusuf Shafi'i has stated that "the first book is Sahih Bukhari and then Sahih Muslim, and these two books are the most Sahih (Correct) books after the Holy Quran."

The fact is that the hadiths of these six books have been criticized by both Sunni and Shiite scholars. For instance, the book Adwa' 'ala al-Sunnah al-Muhammadiyah has shown a part of the problems of the hadiths of Bukhari and Muslim books, citing the research of many Sunni elders. [Abu Riah; Adwa' ‘ala al-Sunnah al-Muhammadiyah, p 302-306] 
On the other hand, the compilation of the books "Al-Mustadrak" and "Al-'Elal" following Kutub al-Sittah shows that, firstly, contrary to what has been claimed, not all the hadiths of these books are correct and the hadiths of Moghoof and even Mawdu' hadith can be seen in them, and secondly not all Sahiha hadiths are collected in these books. Many early and late scholars and researchers have criticized the Sahih hadiths, including Hafez Darqatani, Abu Zara Razi, Ibn Hajar Asqalani, and Abu Bakr Baqalani (as early scholars) [Homman, p 292-303] and Sheikh Mohammad Abdo, Rashid Reza, and Ahmad Amin (contemporary scholars) that all have criticized Bukhari's hadiths [Najmi Siri in Sahihin, p 67-73].

However, the books of Kutub al-Sittah are now well-known and established among the Sunnis with notable credibilities. That is why in this manuscript we intend to explain and draw the image of Imam Ali (A.S.) from the perspective of these books.

Here, the books of Kutub al-Sittah are briefly introduced.

1. Sahih Bukhari or Al-Jame 'Al-Sahih by Abu Abdullah Muhammad bin Ismail Bukhari (256 AH)

2. Sahih Muslim by Abu Al-Hussein Muslim Ibn Hajjaj Qashiri Neyshabouri (261 AH)

3. Sunan Al Abu Dawood collected by Sulayman Ibn Ash'ath Ibn Ishaq Sajestani (275 AH)

4. Sunan Al Tirmidhi collected by Abu Isa Muhammad Ibn Isa Ibn Tanura (279 AH)

5. Sunan al-Sughra (named to Mujtaba) by Abu Abdul Rahman Ahmad Ibn Shoaib (303 AH)

6. Sunan Ibn Majah from Muhammad Ibn Yazid Ibn Majah Qazvini (273 AH)

Sobhi Saleh states that "A distinction differentiates each of the six books. Therefore, if someone wants to study jurisprudence, he or she should read Sahih Bukhari. If someone wants to read the content without margins, he or she should read Sahih Muslim. If someone needs a lot of information in the science of hadith, he or she should read Sunan Al Tirmidhi. If someone wants to learn rules, he or she must read Sunan Abu Dawood. If someone searches for a good division of religious jurisprudence rules, he or she should read the Sunnah of Ibn Majah. However, Sunan al-Sughra covers most of these objectives. [Sobhi Saleh; Sciences of Hadith and its terms, p 209]

\section{Amir Al Momenin Ali (A.S.) from the perspective of Tarajem and Rejal}

Imam Ali (A.S.) is the cousin of the Prophet Muhammad (PBUH) and from Shajareh Al Tayyebeh (a delightful and prominent family). Ibn Maghazli writes from the words of Musab bin Abdullah that "He is Ali (A.S.), the son of Abi Talib, and Abi Talib, the son of Abd al-Muttalib, and Abd al-Muttalib, the son of Hashem, and Hashem, the son of Abd al-Manaf, and Abd al-Manaf, the son of Qusay, and Qusay, the son of the Kelab, and Kelab, the son of Morrah, and Morrah, the son of Ka'b, and so on. [Al Managheb, p $5]$. 
Al-Tirmidhi also introduced his predecessors from the language of Ibn Maghazli, who is the predecessor of Ali Ibn Abi Talib (A.S.). In a narration from "Vathila Ibn Aqsa" from the words of Vathila Ibn Aqsa froM the words of Maghazli, Maghazli says:

"God took Ishmael from the descendants of Abraham, Bani Kenaneh from the descendants of Ishmael, Quraysh from the descendants of Bani Kenaneh, Bani Hashim from the descendants of Quraysh, and me from the descendants of Bani Hashim.

Ibn Athir wrote his nickname as Abu al-Hasan, his mother's name as Fatemeh, the daughter of Asad ibn Hashim, and his family as the first family in which two couples from Bani Hashim were married.

He writes: "He is the son-in-law and wife of the daughter of from the descendants of) Fatima, a female descendent of Prophet Mohammad and best of all women, and the first caliph of Bani Hashim." [Ibn Athir Asad Alghabeh, 283/3]

His mother named him "Heydar".

Muslim, in a long narration of the Khyber war, quoting the bragging of Imam Ali (A.S.) in war and his rivalry against Marhab Khyberi. He quotes from words of Imam Ali (A.S.) that "my mother called me "Heydareh". [Sahiha Muslim; 132/1441/3]

In a narration from the words of Fatima bint Asad, Sheikh Saduq narrates that "I entered the Masjid alHaram (Bait Allah al-Haram) and ate the dates of Paradise. When I wanted to leave, Hatefi called out that Fatima, name him Ali". [Sheikh Saduq, Elal Al Sharaye, 163/3]

His sobriquets include "Vasi" [Zobeydi, Taj Al Arous, 392/10; Ibn Al Manzour, Lesan Al Arab, 394/15], "Morteza", "Heydar" and "Amir al-Mo'menin".

His birth has been recorded on Friday, the 13th of Rajab, 30 years after 'Ām al-Fīl (literally: year of the Elephant) [Tusi, Al Tahzib Al Ahkam, 19/6; Ganji, Kefaya Al Talib, p 407]. The ruler considers the news that indicates Imam Ali (A.S.) was born in the Jouf Al Kaaba (hollow of the Kaaba) to be successive. [Al Mostadrak Elal Sahihin; 6044/550/3]

Zahabi introduces him as one of the foremost in Islam [Tazkirat Al-Hafiz, 10/1], and Ibn Athir writes about him that "According to many scholars, he is the first person to convert to Islam." [Asad Al Ghaba, 283/3].

In his sunan, Tirmidhi introduces him as the first person to believe in the Prophet Muhammad (PBUH) and the first person to pray with him. [Sunan Al Tirmidhi, 306/5, 305, 3818, 3817]

In his document, Nisa'i quotes from the words of Abdullah bin Barida from his father "Abu Bakr and Umar asked for the hand of Fatima in marriage. Muhammad (PBUH) replied she is young. Then, Ali (A.S.) asked her to marry, and the Prophet Muhammad (PBUH) accepted. [Sunan al-Sughra, 62/6; Tazvaj Al Merata Masaloha Fi Alsena]

Ali (AS) made his armor his dowry. [Sunan Abu Dawood, Ketab Al Nekah, 490/1] 
His martyrdom was taken out by Ibn Muljam Moradi, a person from Kharijite. His age at the time of his martyrdom has been written 57 to 63 years. [Ibn Athir, Asad Al Ghaba, 302/3]

Hakim has written the day of his martyrdom in 21 Ramadan [Al Mostadrak, 143/3] and Ibn Hajar has reported it on 17 Ramadan in 40 AH [Al Anaba Fi Al Tamiz Al Sahaba, 468/4].

He has written his caliphate for 4 years, 8 months, and 15 days. [Homman]

\section{Amir Al Momenin in the mirror of narrations of Kutub al-Sitta}

When reviewing the hadiths of Kutub al-Sitta, we face two sets of narrations related to Imam Ali (A.S.): The first group is the hadiths that have been narrated about him and in the honor of his worship from the Prophet Muhammad (PBUH and his companions. The second group is the hadiths that have been narrated from Imam Ali (A.S.) on various subjects.

The most important part of the hadiths that have been narrated on Imam Ali (A.S.) honor is the narrations that are used in the field of proving his Imamah and guardianship, such as Hadith al-Manzila, Hadith alThaqalayn, Hadith al-Wilaya (Ghadir), and more. Furthermore, hadiths have been narrated about the virtues and excellence of Imam Ali (A.S.), which are related to his faith, knowledge, courage, justice, and high position near the Prophet Muhammad (PBUH).

In the following, each of these titles mentions narrations from Kutub al-Sittah, and then several other authentic Sunni hadith sources are also mentioned to confirm the same subject and the same narration. Therefore, the hadiths that may be very famous and successive, but are not cited in Kutub al-Sittah, were excluded. We wich these studies can lead us to present the image of Imam Ali (A.S.) from the perspective of Kutub al-Sittah.

\section{Hadith al-Manzila}

A hadith that has been narrated about Amir al-Mu'minin in four of Sunni's sextuple is the Hadith alManzila. In this narration, the Prophet Muhammad (PBUH) addresses Imam Ali (A.S.) "Are you not satisfied that your position with me is like that of Aaron with Moses?"

For example, Bukhari has narrated in his Sahih in the book "Fazail of Al Ashab Al-Nabi" (Virtues of the Companions of the Prophet Muhammad (PBUH)) about the virtues of Ali Ib Abi Talib "Muhammad ibn Bashar, from Ghandar, from Shu'bah, and from Sa'd narrated that I heard Ibrahim ibn Sa'd narrate from his father that the Prophet Muhammad (PBUH) said Ali: Are you not happy that your position near me is like the position of Aaron in the eyes of Moses". [Sahih Bukhari, Bab Al Managhib Ali Ibn Abi Talib, 208/4]

This has been repeated in the narrations cited in Sahih Muslim, Sunan al-Tirmidhi, and Sunan Ibn Majah [Sahih Muslim, Bab Al Fazl Al Ali Ibn Abi Taleb, 1870/4, 1871, 30, 31, 32; Sunan al-Tirmidhi, Bab Al 
Managhib Ali Ibn Abi Talib, 301-302/5; Sunan Ibn Majah, Bab Al Fazl Al Ali Ibn Abi Taleb, 45/1]. And in most of them, it is stated in the continuation that "there will be no other prophet after me".

\section{The meaning of Hadith al-Manzila}

By reviewing the verses on Aaron and Moses in the Holy Qur'an [Wilaya of Imam Ali (A.S.) in Kitab and Al Sunah, p 52, Ma'alim Al Modaresatayn, 316/1], we conclude that Aaron has been a brother, minister, supporter, colleague, and helper for Moses in his mission and Moses has appointed him as caliph and successor among the ummah to lead and reform the affairs of the people. Therefore, according to these narrations, all these positions (except prophethood) have been assigned to Ali Ibn Abi Talib (A.S.).

Allameh Askari, referring to the word "Menni" (From me) in the above narration, writes "positions of Aaron for Ali (A.S.) include helping and cooperating with the Prophet in retelling the divine commandments and the authority and jurisdiction of his words in religious and propaganda matters for the ummah. [Homam]

\section{Hadith al-Thaqalayn}

Hadith al-Thaqalayn is another hadith that has been narrated from the word of the Prophet Muhammad (PBUH) to prove the Imamah and guardianship of Imam Ali (A.S.) and in his honor.

In this hadith, the Holy Prophet points to the Qur'an and Ahl al-Bayt ("people of the house", Muhammad's family) as the two weighty things, and emphasizes the inseparability of these two until the resurrection and their valuable role in guiding and preventing people from going astray.

This hadith has been narrated in Sahih Muslim and Sunan al-Tirmidhi, among books of Kutub al-Sittah. [Sahih Muslim, Bab Al Fazl Ali Ibn Abi Talib, 1873/4, 36; Sunan al-Tirmidhi, Bab Al Managhib Al Ahlul Bait Al Nabi (Virtues of people of the house", Muhammad's family), 328-329/5, 3876].

This narration has been narrated from the Prophet Muhammad (PBUH) on Hajjat al-Wadā' (meaning: farewell hajj) where he gathered people and talked to them "I will soon respond to the invitation of God and leave you. Before I go to the afterlife, I will leave among you two precious works, one of which is more valuable than the other. Those are the holy Qur'an and my Ahl al-Bayt. So, be careful when dealing with them. These two will never separate until they join me at the Kowsar pond."

Then he takes the hand of Imam Ali (A.S.) and says: "Therefore, for whoever I am his/her leader, Ali (A.S.) is his/her leader too. God, friend his friends and consider his enemy as an enemy".

The ruler considers this hadith to be one of the correct hadiths according to hadith studies rules of Bukhari and Muslim. 


\section{The meaning of the Hadith al-Thaqalayn}

First, the meanings of Ahl al-Bayt and Etrat must be defined in this narration. Muhammad introduced Imam Ali (A.S.) by telling "for whoever I am his/her leader, Ali (A.S.) is his/her leader too" and according to the expressions at the beginning of the sermon that he has announced his death and its imminent, what matters is the issue of his succession and caliphate and introducing a competent person who should take over this matter. Furthermore, this ceremony and these expressions are not anything but appointing a successor and guardian of the Muslims after the Prophet Muhammad (PBUH).

We provide the reader with a narration of Aisha in Sahih Muslim that the Prophet Muhammad (PBUH) covered himself, Imam Ali (A.S.), Lady Fatima (A.S.), Imam al-Hasan (A.S.), and Imam al-Husayn (A.S.) with his kisa' and read Al-Tathir verse, by which clearly expressed his meaning of Ahl al-Bayt.

Muslim quotes in his narration from Aisha "One morning, the Prophet Muhammad (PBUH) wore a clock made of black wool and was about to leave the house. Meanwhile, Hassan Ibn Ali (A.S.) entered. The Prophet covered him with his cloak. Then, Hussein Ibn Ali (A.S.) entered, and the Prophet did the same. After that, Lady Fatima came and the Prophet took her under his cloak. After that, Ali came and the Prophet did the same. Then he recited this verse "Indeed Allah desires to repel all impurity from you, O People of the Household, and purify you with a thorough purification" [Surah Al-Ahzab, Verse 33] [Sahih Mulsim, Bab Al Fazail Al Ahlu Al Bayt Al Nabi, 1883/4,61; Al Mostadrak, 147/3].

This hadith has been narrated differently in the Sunah of Tirmidhi, from the words of Umar ibn Abi Salma. [Sunah of Tirmidhi, 328/5, 3875].

Firoozabadi holds the Hadith al-Thaqalayn a fully valid and strong documentary and considers it as one of the correct, beneficial, and consistent hadiths. [Al Fazail Al-Khamsi Men Al Kutub al-Sitta; 61/2]. Ibn Hajar writes in Al-Sawa'iq: "Hadith al-Thaqalayn has been narrated in many ways by twenty-one companions." [Al-Sawa'iq al-Muhriqah, p 136]

\section{Hadith al-Wilaya (Ghadir)}

The punch line of this hadith is the famous idiom "for whoever I am his/her leader, Ali (A.S.) is his/her leader too" from the Prophet Muhammad (PBUH) that is in the continuation of the Hadith al-Thaqalayn and after the Hajjat al-Wada' of the Prophet in a large crowd in that unbearable heat. Then, the Prophet prayed for him and said: "God, exalt the one who exalts Ali (A.S.) and humiliate the one who humiliates Ali (A.S.)".

Hadith al-Wilaya (Ghadir) is one of the consecutive hadiths that many Sunni books and sources refer to [Al-Ghadir, 294/313/1; Ehghagh Al-Hagh (restoration of rights)], cover 2]. Allameh Amini in "Al-Ghadir" has named 110 companions and 84 followers in alphabetical order who have narrated the hadith of Ghadir [Alghadir, 14-73/1]. He further has mentioned the names of 360 Sunni scholars who have quoted the hadith of Ghadir in their books [Homman, 73-151/1]. Likewise, he has mentioned the name of 26 Sunni 
scholars who have written about the Hadith Al-Ghadir, including ibn Jarīr al-Ṭabarī, Ibn Aqda, Abu Bakr Jaabi, Dar Qatani, Shams al-Din Zahabi, Karajki, Haskani, Ibn Jazri, Abu Sa'id Sajestani, and more. [Al Ghadir, 158-159]

The expression "for whoever I am his/her leader, Ali (A.S.) is his/her leader too" has been narrated again in books of Kutub al-Sittah, Sunnah al-Tirmidhi, and the Sunnah al-Ibn Majah. [Sunnah al-Tirmidhi, 297/5; Sunnah al-Ibn Majah, 43/1]

\section{The meaning of the hadith al Ghadir}

What is disputed in understanding the expression "for whoever I am his/her leader, Ali (A.S.) is his/her leader too" is the meaning of the word leader (Mola), which some have defined as "love and friendship" and, by which, wilaya and guardianship. However, one of the most distinct meanings of the word Mola (leader) is seizing. Moreover, when the guardianship of Ali (A.S.) is similar to that of the Prophet Muhammad (PBUH) and over the people, and his guardianship has been in charge of all the religious and materialistic affairs of the people, applying this word in this meaning is more reasonable and closer to the truth. According to the circumstances governing the time of telling these words and gathering people in that unbearable heat, and then allegiance and greeting people to Ali (A.S.), as well as other evidence, the intention of the Prophet Muhammad (PBUH) by telling the word "Vali" (Leader) is that Ali (A.S.) had the same priority in deciding on religious affairs and supervising the materialistic affairs of the people after Muhammad (PBUH). And knowing him as "Vasi" (Administrator) and "Mola" (Leader) in the literature and poetry of that time [Amini, Al-Ghadir, 340/1] indicate that the Prophet Muhammad (PBUH) on the day of Ghadir Khumm has appointed Amir Al Momenin (A.S.) as the caliph and successor and governor after him.

In Sunah al-Tirmidhi, a narration from the Prophet Muhammad (PBUH) calls Ali (A.S.) with the phrase "Ali (A.S.) is a leader after me". [Sunah al-Tirmidhi, 3796/296/5].

About the literal symmetry of "Men Ba'di" (After me), Firoozabadi writes "the literal symmetry of Men Ba'di shows that "Vali" (Leader) in its most famous meaning implies "owning the thing", and here it means the one who has the right to possess affairs of a person who has been introduced him as the "Vali". [Al Fazail Al Khamsa Men Al Kutub al-Sittah, 6/1]

\section{Hadith "En Al Aemah Men Al Quraysh"}

Among the four books of Kutub al-Sittah, the four books of Sahih Bukhari, Sahih Muslim, Sunan Abu Dawud, and Sunan Tirmidhi have narrated a narration from the Prophet Muhammad (PBUH) who said: Twelve are Amir (commander) and governor. [Sahih Bukhari, Ketab Al-Ahkam, 165/4] 
Or a narration that indicates that "this religion is perpetually steady and lasting until the Last Judgment and as long as 12 caliphs lead you, and all these caliphs are from Quraysh. [Sahih Muslim, Ketab AlEmarat, 1453/3, 1821]

Tirmidhi and Abu Dawood have further gathered narrations close to these themes. [Sunah Abu Dawood, Ketab Al-Mahdi, 106/3]

\section{The meaning of the hadith "En Al Aemah Men Al Quraysh"}

According to words of the Prophet Muhammad (PBUH) in the Hadith al-Thaqalayn that emphasize the inseparability of the Qur'an and the Ahl al-Bayt and that people should be relied upon to prevent misguidance, there must be a caliph from the Prophet Muhammad (PBUH) with the Qur'an to guide human beings over time. This is perfectly in line with the Twelver Shiite belief and truth to Mahdism. According to the opinions of Shiites, there are 12 successors of the Prophet Muhammad (PBUH), with the last one is Imam Mahdi (A.S.) (the Imam of the "Period") who is alive and absent, while (however) people benefit from his existence.

\section{Hadiths on denying administratorship}

Besides the documentary, attached, and correct hadiths narrated from the Prophet Muhammad (PBUH), there are some hadiths narrated by Aisha, Ibn Abbas, and even by Imam Ali (A.S.) in Kutub al-Sittah, which implies that Muhammad (PBUH) has not emphasized the caliphate and the succession. These are not more than two or more hadiths, which we refer to as the hadiths on denying administratorship.

One of these hadiths narrates from Aisha that she replies to those who call Ali (A.S.) the administrator of the Prophet Muhammad (PBUH) "When did he (the Prophet Muhammad (PBUH)) make a will to Ali (A.S.), while his head was between my head and chest at the deathbed and he did not make a will in this regard". [Sahih Muslim, Ketab Al-Vasiah, 19/1257/3; Sahih Bukhari, 143/5]

Or in another narration, they quote from Aisha that "the Prophet Muhammad (PBUH) did not leave a dinar, a dirham, a sheep, or a camel, and did not make a will for anything". [Sahih Muslim, 18/1256/3; Sunan al-Sughra, 229/6; Sunan al-Dawood, 2863/654/1]

Or in a different narration, Bukhari quotes from Talha ibn Musarraf that Abdullah ibn Abi Aufa said that the Prophet Muhammad (PBUH) has made a will to the Holy Qur'an. [Sahih Bukhari; 144/5].

\section{The meaning of hadiths on denying administratorship}

The above narrations and similar narrations, which deny the will of the Prophet Muhammad (PBUH) about Imam Ali (A.S.) or anyone else, attempt to confirm the succession process after Muhammad (PBUH). These narrations never are comparable to documentary and correct hadiths such as Hadith alManzila, Hadith al-Thaqalayn, and Hadith al-Wilaya (Ghadir). On the other hand, who has said that 
Muhammad (PBUH) must make a will in the last minutes of his life. What is better than the huge gathering of people in Ghadir Khum to put up this order and will.

What other than Hadith al-Thaqalayn and Hadith of the Cloak (Hadith-e-Kisa) can clearly express the superiority of Imam Ali (A.S.) over others. Plus, the problem of proposing the hadiths on denying the administratorship and particularizing it" is proof that the problem of administratorship has been commonplace in the society of that time. Preventing the writing of the will of the Prophet Muhammad (PBUH) on Youm el Khamis and all the efforts made to deny making a will about Ali cannot hide the facts. The immediate administratorship of Imam Ali (A.S.) will be proved even with this limited number of narrations that are used on his Imamah and will in Kutub al-Sittah.

\section{Virtues and characters of Amir Al Momenin (A.S.)}

There are hadiths on virtues and characters of Imam Ali (A.S.), as well as about the virtues of the companions of Muhammad (PBUH) in the books of Sahih Bukhari, Sahih Muslim, Sunan al-Tirmidhi, and Ibn Majah. These books do not cover all virtues of Imam Ali (A.S.), but are highly clear and powerful on the other hand. And no hadith or narration has been cited in the books of Kutub al-Sittah in rejecting or denouncing Amir Al Momenin (A.S.). Here, to avoid prolonging this manuscript, we provide these hadiths from the books of Kutub al-Sittah in summary.

The Faith of Amir Al Momenin

1. Ali (A.S.) is the first person who has honorably joined Islam [Tirmidhi, Bab Al Managhib Ali Ibn Abi Talib, 306/5, 3818]

2. Ali (A.S.) was the first person to pray with Muhammad (PBUH) [Tirmidhi, 3817/305/5]

3. Imam Ali (A.S.) stated "I am the creature of God, brother of Muhammad (PBUH), and Seddigh-e Akbar (the greatest truthful), and if anyone after me claims the above features, he is a liar. I prayed earlier than all for seven years. [Sunan Ibn Majah, 441/1, 120]

4. The Prophet Muhammad (PBUH) led to a hadith relating to Ali (A.S.) when he was patching his shoes "He is the one that God has tested him for faith acceptance". [Sunan al-Tirmidhi, $3799 / 298 / 5]$

5. Muhammad (PBUH) told to Ali (A.S.) "Do you want to teach you words by which God forgive you by saying them? Though you are forgiven by God Almighty. [Sunah al-Tirmidhi, Abvab alDaavat (Doors of invitations), 190/5]

6. Al-Tathīr (purification) verse, a part of verse 33 of Sura al-Ahzab (Qur'an 33) has been narrated in the honor of the Ahl al-Bayt. And Muhammad (PBUH) covered Imam Ali (A.S.), Lady Fatima (S.A.), Imam Hassan (A.S.), and Imam Hussein (A.S.) with his cloak and called them his family and prayed for them. [Sahih Muslim, 1883/4, 61; Tirmidhi, $361 \& 328 / 5,3875,3963$ ] 


\section{The knowledge and philosophy of Amir Al Momenin}

1. The Prophet Muhammad (PBUH) said "I am the house of sagacity and Ali (A.S.) is its door". [Sunan al-Tirmidhi, 301/5, 3807]

2. Ali (A.S.) said "Whenever I had a question from the Prophet Muhammad (PBUH), he answered me. And whenever I was silent and had no question, I benefited from his statements". [Sunan alTirmidhi, 301/5, 3806]

3. When the Prophet Muhammad (PBUH) sent Imam Ali (A.S.) to Yemen for judgment, while he was young, he prayed for him: "God, lead his heart and strengthen his tongue". Ali (A.S.) has said: "I had no doubts in my judgment between two people after that pray". [Sunan Ibn Majah, 774/2; Sunan Abu Dawood, 160/2, 3582]

4. Umar ibn al-Khattab has said, "Ali (A.S.) knows about judgment more than all of us". [Sahih Bukhari, 149/5].

5. The Prophet Muhammad (PBUH) stated that "Ali Ibn Abi Talib (A.S.) is more aware of judgment than all people". [Sunan Ibn Majah, 154/55/1].

6. Aisha, replying to a question from her about "anointing on the back of shoes," says "refer to Ali (A.S.), who is more informed than me". [Sahih Muslim, 160/1; Sunan al-Sughra, 84/1; Sunan Ibn Majah, 183/1]

7. In the Treaty of Hudaybiyyah, Ali wrote the peace treaty in his own handwriting and .... [Sahih Bukhari, 167/3; Sahih Muslim, 1409/3, 90]

8. Ali (A.S.) was interpreting the sermons of Muhammad (PBUH) for the people. [Sunan Abu Dawood, $263 / 2,4073]$

9. For fellowship and obtaining divine learnings, Ali (A.S.) was the only one who gave alms and received divine knowledge from Muhammad (PBUH) and acted on the verse. And, it has been quoted from Ali (A.S.) that"O you who have faith! When you converse privately with the Apostle, offer a charity before your private talk" [Surah Al-Mujadila, Verse 12] [Sunan al-Tirmidhi, 80 and 81/5, 3355].

10. Ali (A.S.) said "For me, in the sight of the Prophet Muhammad (PBUH), there was standing and rank that did not exist for any of the people. I was going to see him every morning and saying "God bless you the Prophet, and if he coughed, I would give up and go to my family, otherwise, I would enter and be honored in his presence. [Sunan al-Sughra, 12/3]

11. Ali (A.S.) says "I was allowed to see Muhammad (PBUH) twice round-the-clock, once at night and once a day. When he was praying, then he used to cough. [Sunan Ibi Majah, 3708/1222/2]

\section{The courage of Amir Al Momenin}

1. The Prophet Muhammad (PBUH) said in the battle of Khyber "Tomorrow I will give the flag to a man who is loved by God and his Messenger, and God and his Messenger love him. And it is God 
who will conquer Khyber by his hand". [Sahih Bukhari, 12/4; Sunan Ibn Majah, 43/1; Sahih Muslim, 1871 and 1872/4]

2. The verse (These two contending groups contend concerning their Lord) [Surah Al-Hajj, Verse 19] has been fallen about Badrioun (A group of fighter attending the Battle of Badr), i.e., those who fought the opponents on that day, such as Hamza, Ali (A.S.), Ubaydah ibn Harith, Shiba, Utbah, and Al-Walid ibn Uqba. [Sunan Tirmidhi, 3962/360/5; Sunan Abi Majah, 145/52/11]

\section{Amir Al Momenin, Measurement and Examination}

1. The Prophet Muhammad (PBUH) stated about Ali (A.S.) "God forgives Ali (A.S.). My Lord, wherever Ali (A.S.) is, organize the truth in his hands. [Sunan Tirmidhi, 3798/297/5]

2. The Prophet Muhammad (PBUH) talked to Ali (A.S.) and said "Ali, you will be loved by your believer and opposed by your enemies" [Sunan Tirmidhi, 299 and 306/5; Sahih Muslim, 131/86/1; Sunan al-Sughra, 116/8; Sunan Ibn Majah; 42/1].

3. The Prophet Muhammad (PBUH) talked to Ali (A.S.), Ladi Zahra, Imam Hasan, and Imam Hossein, and said: I will fight with those who are at war with you and will compromise with those who compromise with you". [Sunan Tirmidhi, 3962/360/5; Sunan Abi Majah, 145/52/11]

\section{The position of Amir Al Momenin near the Prophet Muhammad (PBUH)}

1. Ali (A.S.) is the brother of the Prophet Muhammad (PBUH). Ibn Majah has narrated from Ali (A.S.) that he said "I am the creature of God, brother of Muhammad (PBUH), and Seddigh-e Akbar (the greatest truthful), and if anyone after me claims the above features, he is a liar. I prayed earlier than all for seven years". [Sunan Ibn Majah, 44 and 45/1, 120]

2. The Prophet Muhammad (PBUH) addressed Ali (A.S.) "You are my brother in this world and afterlife". [Sunan Tirmidhi, 300/5]

3. Ali is the most beloved creation of God [Hadith al-Tir] [Sunan al-Tirmidhi, 300/5]

4. The Prophet Muhammad (PBUH) addressed Ali "O Ali (A.S.), I love for you what I love for myself and I hate for you what I hat for myself". [Sunan al-Tirmidhi, 58/1]

5. Aisha was asked, which of the men was more beloved to Muhammad (PBUH)? She replied: Fatima's husband was more honorable than others. Yes, he was spending his days fasting and his nights worshiping". [Sunan al-Tirmidhi, 3965/6362/5]

6. One day, Muhammad (PBUH) took the hands of Imam Hassan and Imam Hossein and said: The one who loves me and these two children and their parents will be at the same rank to me at the resurrection. [Sunan al-Tirmidhi, 3965/6362/5]

7. Ladi Fatima was the most beloved woman for Muhammad (PBUH). And the most honorable man was Ali Ibn Abi Talib. [Sunan al-Tirmidhi, 3960/360/5] 
8. The prayer of Ali (A.S.) was reminiscent of the prayer of Muhammad (PBUH). [Sahih Bukhari, 200, 191, 190/1; Sahih Muslim, 8/2, 908; Sunan al-Sughra, 164-167/1; Sunan Ibn Dawood, 84/5; Sunan Ibn Majah, 917/296/1]

9. The Prophet Muhammad (PBUH) addressed Ali "You are from me and I am from you". Then, he added, "he is after me the guardian of all believers". [Sahih Bukhari, 168/3, 207/4; Sunan alSughra, p 88]

10. The Holy Prophet of Islam said: Ali (AS) is from me and I am from Ali (AS) and no one but me or Ali (AS) can fulfill the wishes of the divine religion. [Sunan al-Tirmidhi, 3796/296/5]

11. The Prophet Muhammad (PBUH) said: Ali is from me and me from Ali, and no one other than Ali and me can follow divine tradition and custom. [Sunan al-Tirmidhi, 384/300/5; Sunan Ibn Majah, $119 / 44 / 1]$

12. The Prophet Muhammad (PBUH) selected the nickname "Abu Torab" for Ali (A.S.). [Sahih Bukhari, 207.4; Sahih Muslim, 1874/4; Sunan al-Sughra, p 129]

13. When verse 61, Surah Al Imran was fallen [Should anyone argue with you concerning him, after the knowledge that has come to you, say, 'Come! Let us call our sons and your sons, our women and your women, our souls, and your souls, then let us pray earnestly, and call down Allah's curse upon the liars], Muhammad (PBUH) called Ali (A.S.), Lady Fatima, Imam Hassan (A.S.), and Imam Hossein [A.S.] and said, Lord, these are my Ahl al-Bayt. [Sahih Muslim, Bab Al Fazl Ali Ibn Abi Talib, 32/1871/4; Sunan Tirmidhi, 302/5, 4085/293/4]

14. The Prophet Muhammad (PBUH) ordered Imam Ali (A.S.) to take back the Surah At-Tawbah from Abu Bakr and read it for the people of Mecca and said: Lord has commanded that this Surah shall be narrated just for one who is from my family and has a very close connection with me. And, no one else can read for the people of Mecca.

15. The Prophet Muhammad (PBUH) ordered that all doors to the mosque be closed except in the house of Ali (A.S.). [Sunan Tirmidhi, 305/5]

16. The Prophet Muhammad (PBUH) said "God has ordered me to love four people and he himself loves those four and they are Ali (A.S.), Abu Dharr, Miqdad, and Salman. [Sunan Tirmidhi, 3802/299/5; Sunan Ibn Majah, 149/53/1]

17. The Prophet Muhammad (PBUH) said "Paradise is waiting for three people, Ali (A.S.), Ammar, and Salman. [Sahih Bukhari, 51-53/8; Sahih Muslim, 744/2, 148 and 156/748; Sunan Ibn Majah, 172/61/1; Sunan Abu Dawood, 427 and 429/2, 4763 and 4768]

18. The killing of the Kharijites by the supreme person and the prediction of Muhammad (PBUH) about the Kharijite revolt and their suppression. [Sunan Tirmidhi, 306/5, 3820]

19. The Prophet Muhammad (PBUH) said about Ali: Lord, do not terminate my life until I see Ali (A.S.). [Sunan Tirmidhi, 306/5, 3820] 
20. Muhammad (PBUH) said about Ali (A.S.): O God, remove (hardship) OF heat and cold from Ali (A.S.) [Sunan Ibn Majah, 43/1, 117]

21. Muhammad (PBUH) prayed about Imam Ali (A.S.): O God, circulate the truth around Ali (A.S.) [Sunan Tirmidhi, 3798/297/5]

22. The Prophet Muhammad (PBUH) asked for greetings to himself and to his family, i.e., his Ahl alBayt, and said "peace be upon Muhammad and his holy family, like peace upon Abraham that was praiseworthy and noble. [Sahih Bukhari, 156/7; Sahih Muslim, 305/1; Sunan Ibn Majah, 293/1, 903 and 904; Sunan Abu Dawood, 976-978/221/1; Sunan al-Tirmidhi, 301/1]

Imam Al-Nawawi says, "586 hadiths have been narrated from Ali Ibn Abi Talib (A.S.) from the Prophet Muhammad (PBUH). Bukhari and Muslim agree on 20 hadiths. Bukhari and Muslim have separately reported 9 and 15 hadiths, respectively. [Tahdhib al-Asma wa al-Lughat, 345/1; 'Abd al-Barr, Al Qaulul Jali Fi Managhib Al Imam Ali Karramullaho Vajhahoo (From Jali in virtues of Imam Ali, Allah bless him), p 186]

Therefore, in total, Bukhari and Muslim have quoted 29 and 35 hadiths from him, while the number of hadiths narrated from Abu Hurairah in Sahih Bukhari is 15 times the number of hadiths narrated from Ali Ibn Abi Talib (A.S.). And/or the hadiths narrated from Aisha in Bukhari are more than 7 times the number of hadiths narrated from him.

In general, it should be stated that he is not one of Mokasserin of hadiths of Kutub al-Sittah [Mokasserin: Those who narrate many hadiths from Muhammad (PBUH) and Imams), although there are more narrations about him than the first three caliphs. Most of the hadiths narrated by him are jurisprudential and some are related to historical events and wars of the beginning of Islam.

\section{Conclusion}

The following are the results of reviewing the narrations of Kutub al-Sittah:

The authors of Kutub al-Sittah have depicted the image of Amir al-Mo'menin as a great companion of the Prophet Muhammad (PBUH). He is a great jurist and a restless Mujahid (soldier) and is one of the formers in Islam. Most importantly, Amir al-Mo'menin (A.S.) is from the Ahl al-Bayt of the Muhammad (PBUH) and holds the honor of marrying his daughter. Imam Ali (A.S.) has made all efforts in advancing Islam and its sublime goals. And, due to the familiarity and companionship of the Prophet Muhammad (PBUH), he is a powerful source for expressing the religious rules of Islam. Sections have covered some of his virtues and characters, which, although the truth of the matter has not been fulfilled, is very expressive and valuable and shows the great trust and love of the Prophet Muhammad (PBUH) towards him. The Prophet Muhammad (PBUH) has referred to him as "Wali" (one of God) and "Mawla" (administrator) many times, and in many narrations, he has made him his Ahl al-Bayt and addressed him. 
The authors of Kutub al-Sittah have reported very few hadiths to prove the Wilaya, Imamah, and guardianship of Imam Ali (A.S.) after the Prophet Muhammad (PBUH), and even attempted to deny his guardianship and caliphate after Muhammad (PBUH) by narrating hadiths from Aisha. However, in general, with the same sources, it is possible to see the heavenly and bright of Imam Ali (A.S.) through the hadiths of Kutub al-Sittah.

I assume that the results of these studies bring all Muslims together around faith and the strong divine rope, aiming to bring a bright and promising future not only for the Muslims but for all of humanity.

\section{References}

1. Ali 'Izz al-Din Ibn al-Athir al-Jazari, Ali Ibn Muhammad, 1418 AH, Usd al-ghabah fi marifat alSahabah (The Lions of the Forest and the knowledge about the Companions). Researched by Sheikh Khalil Ma'mun Siha, Beirut, Dar al-Ma'rifah

2. Aḥmad ibn 'Alī Ibn Ḥajar al-'Asqalānī, 1415 AH, al-Iṣābah fī tamyīz al-ṣaḥābah. Researched by Sheikh Adel Ahmad Abdul Al-Mawjoud, Beirut, Dar Al-Kitab Al-Alamiyah.

3. Yusuf ibn Abdallah ibn Mohammed ibn Abd al-Barr, 1412 AH, Al-Isti'ab fi ma'rifat al-ashab. Researched by Ali (A.S.), Muhammad al-Bajawi, Beirut, Dar al-Jail.

4. Abu Abdullah Muhammad ibn Yazeed al-Rabei al-Qazwini, 1373 AH, Sunan Ibn Majah. Correction by Mohammad Fouad Abdul Baqi, Beirut, Dar al-Fikr.

5. Ibn Maghazli, Ali Ibn Mohammad Ibn Mohammad, 1402 AH, Al-Manaqib. Researched by Mohammad Baqir Behboodi, Salamieh Printing House, Tehran.

6. Ibn Manzoor, 1405 AH, Lesan al-Arab, Adab-e Hozeh Press.

7. Abu Riya, Mohammad, Bi Ta, Adwa 'al-Sunnah al-Muhammadiyya, Tehran, Dar al-Kitab alIslami, fifth edition

8. Amini, Abdul Hussein, 1379 AH, Al-Ghadir Fi Ketab al Sunnah and Al Adab, Beirut, Dar AlKitab Al-Arabi.

9. Bukhari, Muhammad ibn Ismail, 1401 AH, Al-Jame 'Al-Sahih, Istanbul Offset, Beirut, Dar alFikr.

10. Tirmidhi, Mohammad Ibn Isa, 1403 AH, Sunan Tirmidhi. Researched by Abdul Rahman Mohammad Uthman, Beirut, Dar al-Fikr.

11. Hakim Neyshabouri, Muhammad ibn Muhammad, 1406 AH, Al-Mustadrak Ali (AS) Al-Sahihin. Researched by Yusuf Al-Marashli, Beirut, Dar Al-Ma'rifah.

12. Hosseini Jalali, Mohammad Reza, 1413 AH, Al Tadvin Al Sunnah Ul Sharifah (Compilation of holy traditions), Qom, Islamic Propaganda Office. 
13. Zahabi, Abu Abdullah Shams al-Din, Introduction Date 1374 AH, Tazkerat al-Hifaz, Beirut, Dar Al-Ahya Al-Tarath Al-Arabi

14. Zebdi, Mohammad Morteza, Taj Al-Arous, Beirut, Maktab al-Hayat.

15. Sajestani Suleiman Ibn Ash'ath, 1410 AH. Researched by Mohammad Al-Laham, Beirut, Dar alFikr 110

16. Sobhi Saleh, 1997, Hadith Sciences and Its Terms Adel Nader Ali (A.S.), Tehran Osweh Publications

17. Saduq, Muhammad ibn Ali (A.S.), 2007 AH, Causes of Sharia, Najaf, Al-Haydariya Library.

18. Tusi, Mohammad Ibn Hassan, 1967, Tahzib Al-Ahkam, Tehran, Islamic Books House.

19. Abdul Bar, Abbas, 1421 AH, Al-Qul Al-Jali Fi Manaqib Al-Imam Ali (AS) Karamullah Vajah, Beirut, Dar Al-Ma'rifah.

20. Asgari, Seyyed Morteza, 1410 AH, Ma'alim al-Moderesetayn, Beirut, Al-Nu'man Foundation.

21. $1424 \mathrm{AH}$, Imam Ali (AS) administratorship in the book and tradition, the publishing center of the World Assembly of Ahl al-Bayt.

22. 1415 AH, The Holy Quran and Revayat al-Modaresetayn, Tehran, Islamic Islamic Assembly.

23. 1978, The Role of Imams in Reviving Religion, Tehran, Islamic Scientific Association Publishing.

24. Firoozabadi, Seyyed Morteza, 1424 AH, Fazail al-Khamsah Men al Kutub al-Sittah ..., Qom, Firoozabadi Publications

25. Maaref, Majid, 1995, a research in the history of Shiite hadith, Tehran, Zareh Cultural and Artistic Institute.

26. 2002, General History of Hadith, Tehran, Kavir, second edition.

27. Najmi, Mohammad Sadegh, 1982, A review of Sahihin, Tehran, Offset Company, Joint Stock Company

28. Nisa'i, Ahmad Ibn Shoaib, Bi Ta, Khasais al-Imam Ali (A.S.) (Characteristics of Imam Ali (A.S.)). Correction by Mohammad Hadi Amini, Nineveh School of Hadith.

29. 1969, Sunan, first edition, Beirut, Dar al-Fikr.

30. Neyshabouri, Mohammad Ibn Muslim, 1972, Sahih Muslim, second edition, edited by Mohammad Fawad Abdabaqi Beirut, Dar Al-Ahya Al-Tarath Al-Arabi. 31- Haithamy, Ahmad Ibn Hajar, 1312 AH, Al-Sawa'iq Al-Muharraqa, Egypt. 